Aldi Masyarakat Kreatif Email:jurnalkreatif.manajemen@gmail.com

\title{
Peran Koperasi Dalam Mengembangkan Potensi Ekonomi Anggota Dan Masyarakat Di Desa Sindanglaya Kecamatan Tanjung Siang Kabupaten Subang Jawa Barat
}

\author{
Jeni Andriani ${ }^{1}$, Umi Rusilowati ${ }^{2}$, Fathorrahman ${ }^{3}$, Moh. Sutoro ${ }^{4}$, Awaluddin Muchtar ${ }^{5}$ \\ 1.3,5 Dosen Prodi Manajemen Fakultas Ekonomi Universitas Pamulang \\ ${ }^{2,4}$ Dosen Pasca Magister Manajemen Universitas Pamulang \\ Email : dosen00436@unpam.ac.id ,dosen00661@unpam.ac.id , \\ dosen01040@unpam.ac.id, dosen01475@unpam.ac.id,, dosen01792@unpam.ac.id
}

\begin{abstract}
Abstrak. Tujuan dari Pengabdian kepada Masyarakat (PKM) ini adalah untuk mengetahui peran koperasi dalam mengembangkan potensi ekonomi anggota dan masyarakat di Desa Sindanglaya Kecamatan Tanjung Siang Subang Jawa Barat.

Metode yang digunakan dalam PKM ini adalah penyuluhan kepada masyarakat desa Sindnaglaya Tanjung Siang Subang, tentang :pemahaman masyarakat terhadap peran koperasi dalam mengembangkan potensi ekonomi anggota. dan pemahaman masyarakat terhadap peran koperasi dalam mengembangkan potensi ekonomi masyarakat.

Hasil dari pelaksanaan PKM ini, diharapkan masyarakat desa Sindanglaya Kecamatan Tanjung Siang Kabupaten Subang Jawa Barat dapat memahami secara optimal peran sebagai anggota koperasi dan masyarakat desa dalam mengembangkan potensi ekonomi yang ada di wilayahya, sehingga terbentuknya masyarakat yang mandiri dan sejahtera.

Kata kunci : Koperasi. Potensi Ekonomi
\end{abstract}

\begin{abstract}
The purpose of Community Service (PKM) is to determine the role of cooperatives in developing the economic potential of members and communities in Sindanglaya Village, Tanjung Siang Subang District, West Java.

The method used in this PKM is counseling to the village community of Sindnaglaya Tanjung Siang Subang, about: community understanding of the role of cooperatives in developing the economic potential of members. and community understanding of the role of cooperatives in developing the economic potential of the community.

The results of the implementation of this PKM, it is hoped that the people of Sindanglaya village, Tanjung Siang District, Subang Regency, West Java, can optimally understand the role of members of cooperatives and village communities in developing the economic potential in their area, so as to form an independent and prosperous community.
\end{abstract}

Key words: Cooperative. Economic Potential 


\section{Loyalitas Kreativitas \\ P-ISSN 2722-2101, E-ISSN 2722-4201 \\ Program Studi Ekonomi Manajemen Universitas Pamulang \\ Jurnal LOKABMAS Kreatif Vol.02,No.01,Maret 2021 Hal. 8-14 \\ Aldi Masyarakat Kreatif Email:jurnalkreatif.manajemen@gmail.com}

\section{PENDAHULUAN}

Jawa Barat selama lebih dari tiga dekade telah mengalami perkembangan ekonomi yang pesat. Saat ini peningkatan ekonomi modern ditandai dengan peningkatan pada sektor manufaktur dan jasa. Untuk wilayah Jawa Barat terdiri atas 18 kabupaten dan 9 kota. Salah satunya adalah Kabupaten Subang. Kabupaten ini berbatasan dengan Laut Jawa di utara, Kabupaten Indramayu di timur, Kabupaten Sumedang di tenggara, Kabupaten Bandung Barat di selatan, serta Kabupaten Purwakarta dan Kabupaten Karawang di barat.

\section{Berdasarkan Peraturan}

Daerah Kabupaten Subang Nomor 3 Tahun 2007, Wilayah Kabupaten Subang terbagi menjadi 30 kecamatan, yang dibagi lagi menjadi 245 desa dan 8 kelurahan. Pusat pemerintahan berada di Kecamatan Subang. Kabupaten Subang terdiri dari 30 kecamatan, 8 kelurahan, dan 245 desa. Pada tahun 2017, jumlah penduduknya mencapai 1.552.925 jiwa dengan luas wilayah $1.893,95 \mathrm{~km}^{2}$ dan sebaran penduduk 820 jiwa $/ \mathrm{km}^{2}$. Tanjungsiang adalah salah satu kecamatan di Kabupaten Subang. Topografi Tanjungsiang adalah pegunungan dengan ketinggian 700 meter di atas permukaan. Sindanglaya adalah salah satu desa di kecamatan Tanjung Siang, Subang, Jawa Barat, yang menjadi tempat Pengabdian kepada Masyarakat, dengan sebagian mata pencaharian penduduknya bergerak di bidang pertanian, perikanan dan peternakan.

Salah satu yang menopang perkembangan ekonomi yang pesat di Jawa Barat adalah keberadaan Koperasi dan UMKM. Sejalan dengan perkembangan koperasi di wilayah Jawa Barat, khususnya kabupaten Subang, berdasarkan data dari Dinas Koperasi dan Usaha Kecil Jawa Barat tahun 2017, terdapat 917 Koperasi dengan prosentasi Koperasi yang aktif $81 \%$, hal ini menunjukan perkembangan yang Sudah baik tentang keberadaaan Koperasi namun tetap harus dilakukan terus menerus sosialisasi mengenai Peran Koperasi dalam Mengembangkan Potensi Ekonomi baik Anggota Koperasi itu sendiri maupun Masyarakat sekitar.
Koperasi sebagai soko guru perekonomian nasional memiliki 5 wahana pokok, yaitu wahana ekonomi, wahana pendidikan, wahana perdemokrasian ekonomi masyarakat, wahana pengimbang antara aparatur ekonomi swasta, wahana persatuan dan kesatuan bangsa, berperan $\mathrm{dlm}$ menumbuhkan etika, semangat kebersamaan, kesetiakawanan dan kekeluargaan. Dalam perjalanan hidupnya citacita koperasi sebagai soko guru perekonomian indonesia telah mengalami pasang surut sesuai kehendak zaman. Sebelum orba koperasi telah berkembang utk menentang ekonomi kapitalis. akan tetapi, dalam perkembangannya baru secara kuantitatif.

Menurut UU No. 25/1992, koperasi adalah badan usaha yang beranggotakan orangseorang atau badan hukum koperasi, dengan melandaskan kegiatannya berdasarkan prinsip koperasi sekaligus sebagai gerakan ekonomi rakyat, yang berdasarkan asas kekeluargaan. Koperasi bertujuan memajukan kesejahteraan anggota pada khususnya dan masyarakat pada umumnya, serta ikut membangun tatanan perekonomian nasional, dalam rangka mewujudkan masyarakat yang maju, adil, dan makmur berlandaskan Pancasila dan UUD 1945.

Dengan makin berkembangnya kegiatan usaha koperasi tuntutan akan pelaksanaan pengelolaan koperasi secara profesional semakin besar Semuanya ini dapat tercapai apabila koperasi sebagai badan usaha yang bergerak di bidang ekonomi melaksanakan kegiatan usahanya dengan menyesuaikan diri dengan perkembanganperkembangan yang terjadi. Dengan demikian dapat dikaitkan bahwa perkembangan koperasi merupakan hal yang sangat penting untuk kelangsungan hidup koperasi.Dengan kedudukan dan peranan koperasi yang demikian dan sesuai dengan kebijaksanaan program pembangunan koperasi dalam era reformasi yang dititik beratkan pada upaya memandirikan koperasi, reposisi peran koperasi pada hakikatnya ditujukan menyelaraskan peran koperasi, sesuai dengan ide dan prinsip dasarnya.

Hal ini menjadi tugas bersana antara pemerintah pusat dan perangkat desa setempat 


\section{Loyalitas Kreativitas}

P-ISSN 2722-2101, E-ISSN 2722-4201

Program Studi Ekonomi Manajemen Universitas Pamulang

Jurnal LOKABMAS Kreatif Vol.02,No.01,Maret 2021 Hal. 8-14

Aldi Masyarakat Kreatif Email:jurnalkreatif.manajemen@gmail.com

serta masyarakat untuk mengembangkan potensi ekonomi wilayah desa dengan keberadaaan koperasi setempat. Perlu adanya sosialisasi terus menerus supaya lebih optimal hasilnya untuk kemajuan bersama.

Berdasarkan hasil survey pendahuluan oleh Tim Pengabdian Kepada Masyarakat (PKM) ke lokasi dan melakukan wawancara, observasi, serta Fokus Group Diskusi (FGD) dengan Bapak Kepala Desa, Bapak E. Endang Jaelani, beserta staf, dan tokoh masyarakat, Bapak Dr. Nurzaman, A.M, M.M., M.Si , di Desa Sindanglaya Kecamatan Tanjung Siang Kabupaten Subang Jawa Barat, sudah ada koperasi di tingkat desa, yaitu Kopwan Led Desa Sindaglaya, namun belum semua masyarakat desa tahu perannya koperasi, sehingga kami dari Universitas Pamulang membantu mensosialisasikan dengan mengadakan kegiatan Pengabdian kepada Masyarakat dengan judul "Peran Koperasi Dalam Mengembangkan Potensi Ekonomi Anggota dan Masyarakat Desa Sindanglaya Kecamatan Tanjung Siang Kabupaten Subang Jawa Barat"

Rumusan masalah kegiatan PKM ini adalah sebagai berikut :

1. Bagaimana masyarakat desa bisa memahami secara optimal peran sebagai anggota koperasi?

2. Bagaimana masyarakat desa bisa memanfaatkan secara optimal peran koperasi dalam mengembangkan potensi ekonomi yang ada di wilayahya?

Tujuan kegiatan PKM ini adalah sebagai berikut:

1. Untuk mengetahui secara optimal bagaimana masyarakat desa memahami peran sebagai anggota koperasi.

2. Untuk mengetahui secara optimal bagaimana masyarakat desa memahami peran koperasi dalam mengembangkan potensi ekonomi yang ada di wilayahya.

\section{METODE PELAKSANAAN}

Metode kegiatan ini berupa pelatihan kepada masyatrakat yang ada di Desa Sindanglaya, Kami melakukan persiapan segala hal yang terkait dengan materi, bahan dan alat sesuai dengan tema secara baik. Hasil persiapan tersebut dimaksudkan agar materi tersampaikan dengan mudah dimengerti serta dipahami oleh Masyarakat pada Desa Sindanglaya, Kec. Tanjungsiang, Kab. Subang.
Berikut ini adalah tahapan pelatihan yang dilakukan

1. Membantu masyarakat dalam memahami peran sebagai anggota koperasi.

Dalam hal ini sebagai solusinnya maka kepada masyarakat di Desa Sindanglaya Tanjung Siang Subang, di berikan pemahaman tentang tujuan dan manfaat serta peranan koperasi sesuai UU No. 25 Tahun 1992, yaitu Koperasi adalah badan usaha yang beranggotakan orang-orang atau badan hukum koperasi, dengan melandaskan kegiatannya berdasarkan prinsip koperasi sekaligus sebagai gerakan ekonomi rakyat yang berdasar atas azas kekeluargaan. Beberapa kewajiban dan hak anggota koperasi. Kawajiban anggota diantaranya, yaitu :
a). membayar simpanan pokok dan simpanan wajib,
b). mengembangkan koperasi,
c). memelihara kebersamaan,
d). menjaga kerahasiahan,
e). memodali koperasi,
f). menghadiri rapat.

Sedangkan Hak anggota diantarany, yaitu :
a). memilih pengurus,
b). memberikan pendapat dan saran,
c). mendapat pelayanan yang sama,
d). mendapat keterangan tentang keadaan keuangan,
e). memanfaatkan pelayanan koperasi,
f). menjadi pelanggan yang tetap.

2. Peranan koperasi masih belum dimanfaatkan secara optimal oleh seluruh anggota. masyarakat

Dalam hal ini sebagai solusinnya maka kepada masyarakat di Desa Sindanglaya Tanjung Siang Subang, di berikan pemahaman tentang peranan koperasi sesuai UU No. 25 Tahun 1992, Pasal 4, Peran dan Fungsi Koperasi adalah: Membangun dan mengembangkan potensi dan kemampuan ekonomi anggota pada khususnya dan masyarakat pada umumnya untuk meningkatkan kesejahteraan ekonomi dan sosialnya.

Berikut ini masalah yang dihadapi koperasi secara umum dan cara mengatasi permasalahan tersebut, yaitu :

a. Koperasi jarang peminatnya

Koperasi jarang peminatnya dikarenakan ada pandangan yang berkembang dalam masyarakat bahwa koperasi adalah usaha 


\section{P-ISSN 2722-2101, E-ISSN 2722-4201 \\ Program Studi Ekonomi Manajemen Universitas Pamulang \\ Jurnal LOKABMAS Kreatif Vol.02,No.01,Maret 2021 Hal. 8-14 \\ Aldi Masyarakat Kreatif Email:jurnalkreatif.manajemen@gmail.com}

bersama yang diidentikkan dengan masyarakat golongan menengah ke bawah. Dari sinilah perlu adanya sosialisasi kepada masyarakat tentang koperasi. Dengan adanya sosialisasi diharapkan pengetahuan masyarakat tentang koperasi akan bertambah. Masyarakat dapat mengetahui bahwa sebenarnya koperasi merupakan ekonomi rakyat yang dapat menyejahterakan anggotanya. Sehingga mereka berminat untuk bergabung.

b. Kualitas Sumber Daya yang terbatas

Sumber Daya Manusia yang kurang. Sumber daya manusia yang dimaksud adalah pengurus koperasi. Seperti yang sering dijumpai, pengurus koperasi biasanya merupakan tokoh masyarakat sehingga dapat dikatakan rangkap jabatan, kondisi seperti inilah yang menyebabkan ketidakfokusan terhadap pengelolaan koperasi itu sendiri. Selain rangkap jabatan biasanya pengurus koperasi sudah lanjut usia sehingga kapasitasnya terbatas.

c. Banyaknya pesaing dengan usaha yang sejenis.

Pesaing merupakan hal yang tidak dapat dielakkan lagi, tetapi kita harus mengetahui bagaimana menyikapinya. Bila kita tidak peka terhadap lingkungan (pesaing) maka mau tidak mau kita akan tersingkir. Bila kita tahu bagaimana menyikapinya maka koperasi akan dapat bertahan dan berkembang. Dalam menanggapi pesaing kita harus mempunyai cara khusus, misalnya, melalui harga barang/jasa, sistem kredit dan pelayanan yang maksimum. Mungkin koperasi sulit untuk bermain dalam harga, tapi hal ini dapat dilakukan dengan cara sistem kredit, yang pembayarannya dapat dilakukan dalam waktu mingguan ataupun bulanan tergantung perjanjian. Dengan adanya hal seperti ini diharapkan dapat menarik perhatian masyarakat untuk menjadi anggota.

d. Keterbatasan Modal

Masalah permodalan adalah masalah klasik. Dengan pemberian modal koperasi dapat memperluas usahanya sehingga dapat bertahan dan bisa berkembang. Sebagai pemberi modal selain pemerintah, masyarakat merupakan pihak yang tak kalah pentingnya, dimana mereka yang memiliki dana lebih dapat menyimpan uang mereka dikoperasi yang nantinya dapat digunakan untuk modal koperasi.

e. Partisipasi anggota

Sebagai anggota dari koperasi seharusnya mereka mendukung program-program yang ada di koperasi dan setiap kegiatan yang akan dilakukan harus melalui keputusan bersama dan setiap anggota harus mengambil bagian di dalam kegiatan tersebut.

f. Perhatian pemerintah

Pemerintah harus bisa mengawasi jalannya kegiatan koperasi sehingga bila koperasi mengalami kesulitan, koperasi bisa mendapat bantuan dari pemerintah, misalnya saja membantu penyaluran dana untuk koperasi. Akan tetapi pemerintah juga jangan terlalu mencampuri kehidupan koperasi terutama hal-hal yang bersifat menghambat pertumbuhan koperasi. Manajemen koperasi

g. Dalam pelaksanaan koperasi tentunya memerlukan manajemen,

Baik dari bentuk perencanaan, pengorganisasian, pengarahan, dan pengawasan. Karena hal ini sangat berfungsi dalam pengambilan keputusan tetapi tidak melupakan partisipasi dari anggota.

\section{Realisasi Pemecahan Masalah}

Berdasarkan solusi yang diusulkan maka target yang diharapkan sebagai berikut:

1. Masyarakat di Desa Sindanglaya Tanjung Siang Subang memahami tentang hak dan kewajiban, tujuan dan manfaat koperasi dalam upaya mensejahterakan anggotanya sesuai ketentuan yang berlaku

2. Masyarakat di Desa Sindanglaya Tanjung Siang Subang memahami tentang peran koperasi dalam mengembangkan potensi ekonomi untuk meningkatkan kesejahteraan.

3. Perangkat desa membantu untuk terus menerus mensosialisasikan keberadaaan koperasi yang sudah ada kepada masyarakat desa.

\section{Khalayak Sasaran}

Peserta kegiatan : Masyarakat desa Sindanglaya Tanjung Siang Subang 


\section{Loyalitas Kreativitas \\ P-ISSN 2722-2101, E-ISSN 2722-4201 \\ Program Studi Ekonomi Manajemen Universitas Pamulang \\ Jurnal LOKABMAS Kreatif Vol.02,No.01,Maret 2021 Hal. 8-14 \\ Aldi Masyarakat Kreatif Email:jurnalkreatif.manajemen@gmail.com}

\section{Tempat dan Waktu}

Tempat Kegiatan TK Aulia Desa Sindanglaya Tanjung Siang Subang

Waktu Pelaksanaan : Kamis- Jumat, 23- 24 Januari 2020 Jam 09.00 - 15.00 WIB

\section{Metode Kegiatan}

Metode yang digunakan dalam kegiatan Pengabdian Kepada Masyarakat (PKM) ini adalah melalui kegiatan penyuluhan kepada masyarakat desa Sindnaglaya Tanjung Siang Subang, tentang :

1. Pemahaman masyarakat terhadap peran koperasi dalam mengembangkan potensi ekonomi anggota.

2. Pemahaman masyarakat terhadap peran koperasi dalam mengembangkan potensi ekonomi masyarakat.

Adapun metode sebelum dan sesudah pelaksanaan PKM, adalah sebagai berikut :

1). Metode Pengumpulan Data

Untuk memperoleh data yang akurat yang dapat dipercaya kebenarannya dan relevan, maka pengumpulan data dilakukan dengan beberapa metode yaitu :

a. Wawancara

Merupakan proses untuk memperoleh data dengan cara melakukan pertanyaan, dalam hal ini dilakukan dengan Bapak Dr. Nurzaman, A.M, M.M., M.Si, selaku tokoh masyarakat di Desa Sindanglaya Kecamatan Tanjung Siang Kabupaten Subang Jawa Barat

b. Observasi

Merupakan proses pengumpulan data dengan mengadakan pengamatan langsung pada objek Pengabdian Kepada Masyarakat (PKM) untuk memperoleh data yang diperlukan, dengan melakukan survey langsung ke tempat PKM.

\section{c. . Fokus Grup Diskusi (FGD)}

Merupakan proses pengumpulan data dengan cara diskusi kelompok secara sistematis dan terarah mengenai pokok permasalahn Pengabdian Kepada Masyarakat (PKM). Dalam hal ini FGD dilakukan dengan Bapak E. Endang Jaelani selaku Kepala Desa Sindanglaya Tanjung Siang Subang Jawa barat dan Bapak Dr. Nurzaman,
A.M, M.M., M.Si, selaku tokoh masyarakat.

d. Dokumen

Dokumen merupakan catatan peristiwa yang sudah berlalu, biasanya berbentuk tulisan, gambar, atau karya-karya monumental dari seseorang. Studi dokumen merupakan pelengkap dari penggunaan observasi dan wawancara. Dalam hal ini dilakukan dokumentasi berupa surat menyurat melakukan PKM di desa Sindanglaya Tanjung Siang Subang Jawa Barat

2) Metode Pelaksanaan

Metode pelaksanaan kegiatan ini berupa penyuluhan kepada masyarakat desa Sindanglaya Tanjung Siang Subang Jawa Barat. Adapun tahapan yang dilakukan adalah sebagai berikut :

1. Tahap Persiapan

Tahap persiapan yang dilakukan meliputi :

a. Informasi awal, pada tahap ini didapatkan infomasi awal dari salah satu tokoh masyarakat desa Sindanglaya Tanjung Siang Subang Jawa Barat , Bapak Dr. Nurzaman, A.M, M.M., M.Si., yang menginformasikan bahwa masyarakat desanya belum memahami secara optimal peran koperasi baik secara khusus untuk anggota maupun secara umum untuk masyarakat desa.

b. Pemantapan dan penentuan lokasi dan sasaran. Setelah informasi awal maka ditentukan lokasi pelaksanaan dan sasaran peserta kegiatan penyuluhan. Dengan melakukan proses perijinan secara lisan terlebih dahulu untuk diadakan PKM di lokasi tersebut kepada Kepala Desa Sindanglaya Tanjung Siang Subang Jawa Barat, Bapak E. Endang Jaelani, dan setelah persetujuan ditentukan waktu pelaksanaan PKM yang akan diadakan pada tanggal 24 - 25 Januari 2020 dan bertempat di TK Aulia (usulan semula di Balai desa) Desa Sindanglaya Tanjung Siang Subang Jawa Barat dengan jumlah peserta sebanyak 30 orang,

c. Penyusunan bahan/materi penyuluhan yang meliputi: slide presentasi (power point) dan makalah/materi untuk kegiatan penyuluhan berupa materi 


\section{Loyalitas Kreativitas \\ P-ISSN 2722-2101, E-ISSN 2722-4201 \\ Program Studi Ekonomi Manajemen Universitas Pamulang \\ Jurnal LOKABMAS Kreatif Vol.02,No.01,Maret 2021 Hal. 8-14 \\ Aldi Masyarakat Kreatif Email:jurnalkreatif.manajemen@gmail.com}

Peranan Koperasi baik untuk anggota maupun masyarakat dengan sumber referensi dari buku-buku, jurnal maupun internet.

d. Persiapan perlengkapan penyuluhan, laptop dan LCD, spanduk kegiatan.

\section{Tahap Pelaksanaan Penyuluhan}

Tahap ini akan menjelasan tentang materi Peranan Koperasi baik untuk anggota maupun masyarakat di mana sessi ini menitikberatkan pada pemaparan materi mengenai pengembangan potensi ekonomi untuk mencapai kesejahteraan anggota dan masyarakat, selanjutnya dilakukan tahap diskusi dan tanya jawab.

3. Metode tanya jawab sangat penting bagi para peserta pelatihan. Metode ini memberi kesempatan kepada peserta untuk menanyakan hal-hal yang masih kurang atau belum jelas dalam penyuluhan yang sudah disampaikan.

\section{HASIL DAN PEMBAHASAN}

Masyarakat desa Sindanglaya Tanjung Siang Subang dalam mengikuti penyuluhan sangat bersemangat dan antusias sehingga hasil kegiatan sangat memuaskan, disamping karena belum pernah mendapatkan materi perkoperasian secara detail dan jelas dan kurangnya informasi yang akurat mengenai keberadaan koperasi di desa.

. Dalam tanya jawab, juga peserta cukup banyak yang bertanya seputar peran koperasi dan fungsinya serta manfaat yang akan di dapat sebagai anggota koperasi khususnya, dan masyarakat desa umumnya.

Pada tahap akhir dilakukan pengisian angket/kuesioener mengenai pemahaman peran koperasi dalam mengembangkan potensi anggota dan masyarakat desa, sebagai tolak ukur hasl kegiatan PKM ini bisa bermanfaat untuk anggota koperasi dan masyarkat.

\subsection{Pembahasan}

\section{Hari pertama, Kamis, 23 Januari 2020}

Kegiatan intinya berupa penyuluhan dengan penyampaian materi tentang dasar-dasar perkoperasian pada masyarakat desa Sindanglaya Tanjung Siang Subang dengan tujuan untuk mengetahui secara optimal bagaimana masyarakat desa memahami peran sebagai anggota koperasi, selanjutnya dilakukan tahap diskusi dan tanya jawab. Penyampaian materi diberikan oleh tim PKM.

\section{Hari kedua, Jumat, 24 Januari 2020}

Kegiatannya berupa penyuluhan dengan penyampaian materi tentang peran koperasi dalam mengembangkan potensi ekonomi pada masyarakat desa Sindanglaya Tanjung Siang Subang dengan tujuan untuk mengetahui secara optimal bagaimana masyarakat desa memahami peran koperasi dalam mengembangkan potensi ekonomi yang ada di wilayahya, selanjutnya dilakukan tahap diskusi dan tanya jawab.

Penyampaian materi diberikan oleh tim PKM.

\section{KESIMPULAN DAN SARAN}

\section{Kesimpulan}

Dengan diadakannya kegiatan PKM ini dapat diambil kesimpulan sebagai berikut :

1. Masyarakat desa Sindanglaya Tanjung Siang Subang Jawa Barat belum semuanya memahami secara optimal peran sebagai anggota koperasi dikarenakan masih kurangnya sosialisasi tentang perkoperasian secara meluas.

2. Masyarakat desa Sindanglaya Tanjung Siang Subang Jawa Barat belum semuanya memanfaatkan secara optimal peran koperasi dalam mengembangkan potensi ekonomi yang ada di wilayahya dikarenakan ketidaktahuan peran koperasi yang sudah ada/berjalan di tingkat desa.

\section{Saran}

1. Perlu adanya sosialisasi ke masyakarat desa secara terus menerus dengan mengadakan pertemuan-pertemuan rutin.

2. Perlu dukungan baik dari pengurus koperasi yang sudah ada/berjalan dan aparat desa untuk mengajak masyarakat berpartispasi menjadi anggota koperasi.

\section{DAFTAR PUSTAKA}

Andriani, Jeni dan Sigit Purnomo. 2019. Pengaruh Budaya Organisasi dan Displin Kerja Terhadap Produktivitas Kerja Karyawan Pada Koperasi Simpan Pinjam Sejahtera Bersama Bogor. Jurnal Ilmiah Feasible Vol 1 No. 2, p. 160-169

Elburdah, R. P., Pasaribu, V. L. D., Rahayu, S., Septiani, F., \& Metarini, R. R. A. (2021). 


\section{Loyalitas Kreativitas}

P-ISSN 2722-2101, E-ISSN 2722-4201

Program Studi Ekonomi Manajemen Universitas Pamulang

Jurnal LOKABMAS Kreatif Vol.02,No.01,Maret 2021 Hal. 8-14

Aldi Masyarakat Kreatif Email:jurnalkreatif.manajemen@gmail.com

\begin{abstract}
MOMPRENEUR
PEREKONOMIAN KELUARGA DI MASA

PANDEMI COVID-19 DENGAN BISNIS

ONLINE PADA KELURAHAN PONDOK

BENDA. Abdi Laksana: Jurnal Pengabdian

Kepada Masyarakat, 2(1), 75-82
\end{abstract}

https://jojonomic.com/blog/peran-koperasi/, diakses tanggal 1 Maret 2020

http://repository.uin-suska.ac.id.. Tinjauan Pustaka Potensi, di akses tanggal 29 Juli 2020

https://thidiweb.com/pengertian-ekonomi-sertaprinsipnya/, diakses tanggal 29 Juli 2020

Priadi, A., Pasaribu, V. L. D., Virby, S., Sairin, S., \& Wardani, W. G. (2020). Penguatan Ekonomi Kreatif Berbasis Sumber Daya Desa Dikelurahan Rempoa. Abdi Laksana: Jurnal Pengabdian Kepada Masyarakat, 1(3), $356-358$

Pusat Penelitian Badan Dewan Perwakilan Rakyat Indonesia. 2018. Koperasi Dalam Ssitem Perekonomian Indonesia. Jakarta : Gramedia

Subandi. 2010. Ekonomi Koperasi (Teori dan Praktek). Bandung : Alfabeta

Sudaryana, Yayan, Masno Marjohan, Khayatun Nufus, Jeni Andriani, Maswarni. 2020. Bimbingan Teknis Manajemen Peningkatan Penjualan Melalui Ecommerce Kepada IKM/UKM Koperasi Patih Di Kelurahan Cempaka Putih Kecamatan Ciputat Kota Tangerang Selatan Provinsi Banten. Jurnal Pengabdian Dharma Laksana Vol 3 No. 1, p. 51-56

UU No. 25 Tahun 1992 tentang Koperasi www.subang.go.id, diakses tanggal 1 April 2020 Zulhartati, Sri. 2010. Peranan Koperasi dalam Perekonnomian Indonesia. Jurnal Untan Vol. 25 No. 1

\section{LAMPIRAN : FOTO KEGIATAN}
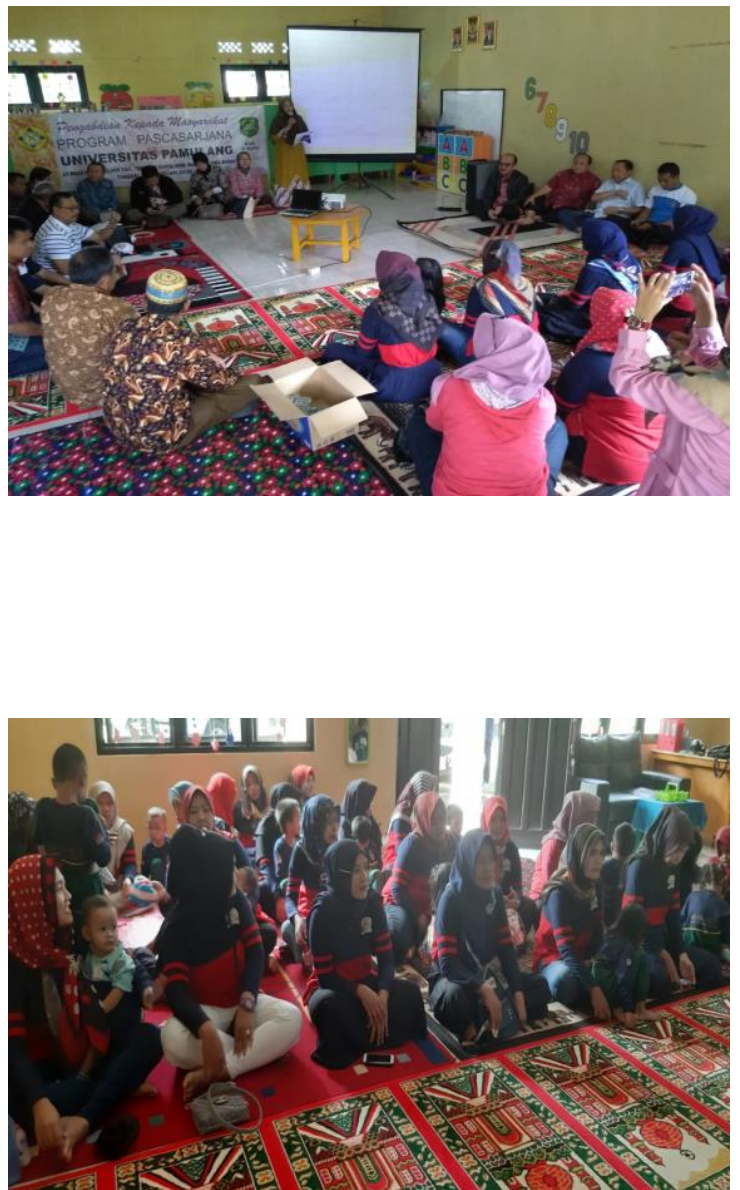
Loyalitas Kreativitas

P-ISSN 2722-2101, E-ISSN 2722-4201

Program Studi Ekonomi Manajemen Universitas Pamulang

Jurnal LOKABMAS Kreatif Vol.02,No.01,Maret 2021 Hal. 8-14

Aldi Masyarakat Kreatif Email:jurnalkreatif.manajemen@gmail.com 